\title{
IMPLEMENTING AND EVALUATING OF HIGH RESOLUTION REMOTE IMAGING SYSTEM USING UNMANNED AIR VEHICLE
}

\author{
Le Van Trung ${ }^{(1)}$, Nguyen Anh Thi ${ }^{(2)}$ \\ (1) Information Technology Park, VNU-HCM \\ (2) VNU-HCM \\ (Manuscript Received on April $5^{\text {th }}, 2012$, Manuscript Revised June $6^{\text {th }}$, 2011)
}

\begin{abstract}
A high resolution remote imaging system using a vertical take-off and landing helicopter- type unmanned air vehicle has been built and successfully tested. The aircraft is navigated using differential GPS and autonomously tracked a set of waypoints defined on Google map. The vertical take-off and landing-type aircraft is chosen due to its high maneuverability and its capability to flight in condensed area with physical obstacles. The aircraft was planned to flight and taken pictures at low altitude changing from $10 \mathrm{~m}$ to $300 \mathrm{~m}$. The experimental results shown that the image resolution in horizontal plan and vertical plan is lower than $3 \mathrm{~cm}$ and $20 \mathrm{~cm}$, respectively. These initial results open a new way for building high resolution remote image for small area and in real-time for diverse civil and military applications.
\end{abstract}

Keywords: Unmanned Air Vehicle, Vertical Take-Off and Landing, Remote imaging

\section{INTRODUCTION}

To observe and reconstruct the Earth surface, images taking from satellites and aircrafts are commonly used. These two remote imaging techniques as being applied for small areas result in low-resolution images with relatively high-cost. In addition, these two techniques are not able to provide images in real-time (at a prescribed time). Recent experimental studies [1-7] show that the shortcomings of above-mentioned imaging techniques can be overcame by the remote imaging system based upon unmanned air vehicle (UAV). Figure 1 summarizes the resolution in horizontal plan of images obtained by different imaging techniques. The remote imaging system based upon UAV taking images from low altitude (from $10 \mathrm{~m}$ to $300 \mathrm{~m}$ ) provides spatial resolution that can be lower than $10 \mathrm{~cm} \mathrm{[7].}$

To develop remote imaging techniques that is able to provide high resolution, real-time images for social applications and economic development, as well as for national security applications is important items of Viet Nam's strategy in space research and applications until 2020 officially approved by the Prime Minister on June 2006, according to the Decision number 137/2006/QĐ-TTg. However, Viet Nam has been mainly using satellite images (taken from $500 \mathrm{~km}$ to $900 \mathrm{~km}$ altitudes) and images taken from aircraft for altitudes from

Trang 35 
$300 \mathrm{~m}$ to $1.000 \mathrm{~m}$. The high-resolution imaging system based upon UAV being capable of taking images from low altitudes ranging from $10 \mathrm{~m}$ to $300 \mathrm{~m}$ is highly demanded and promisingly applied in many social-economic and military applications, such as: hydraulic dam observation, aquarium plants observation, plant classification, quick discovery of filled canals, rescue planning support, urban management, environmental observation, large scale map used in military surveillance,....

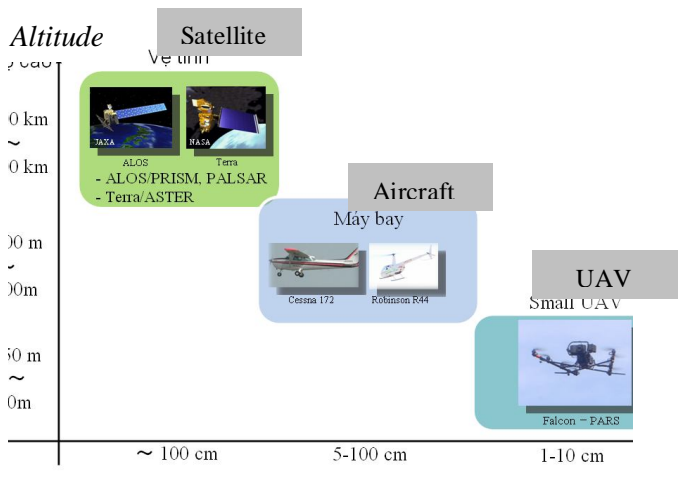

Spatial resolution in horizontal plan

Figure 1. The resolution in horizontal plan of different remote imaging techniques

This study presents the experimental results of high-resolution remote imaging system based upon UAV conducted in Viet Nam. The paper is organized into four sections.
The technical specifications of UAV is presented in Section 2. Experimental imaging flights and taken image resolution evaluation are presented in Section 3. Section 4 draws major conclusions and discusses further required studies.

2. DESCRIPTION OF REMOTE IMAGING SYSTEM USING UNMANNED AIR VEHICLE

UAV-based high-resolution remote imaging system has been experimented and evaluated under Viet Nam real conditions. Images were continuously taken at prescribed GPS-defined positions and sent to ground station for further analysis. UAV-based remote imaging system includes following main equipments:

+ AscTec Falcon 8 (UAV);

+ Global Positioning System (GPS);

+ High resolution camera;

+ Flight planning procedure and image processing softwares.

The main contribution of this study involve the development of flight planning procedure development and image reconstruction software based upon overlapped images taken by camera. 


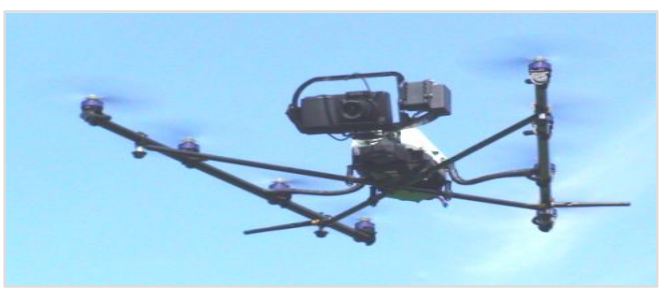

(a) AscTec Falcon 8

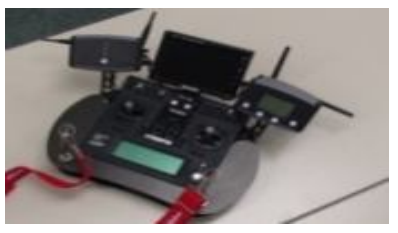

(b) Ground station control equipment

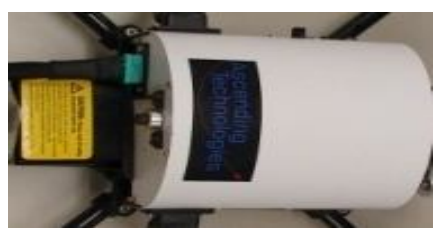

(c) IMU and battery

Figure 2. Unmanned air vehicle (UAV) used and its equipments

\subsection{Unmanned air vehicle}

The UAV-based remote imaging system is developed using a commercially available, low-cost aircraft, namely called AscTec Falcon 8, a vertical take-off and landing (VTOL) aircraft imported and assembled by ISTS (see Figure 2(a)) [10]. The aircraft major technical specifications include:

+ Maximum take-off weight: $1.8(\mathrm{~kg})$;

+ Payload capacity: 500 (g);

+ Flight time: 20 - 30 minutes (limited by battery capacity);

+ Maximum sustainable wind speed: $10 \mathrm{~m} / \mathrm{s}$

+ Image transfer frequency: 5.8 GHz;

+ Control signal frequency from ground station (see Figure 2(b)): $2.4 \mathrm{GHz}$.

\subsection{Global Positioning System (GPS)}

To increase the positioning accuracy, differential GPS (DGPS) that consists of two GPS receivers (U-block LEA-4T) is used: one is installed on the aircraft and another one is planed on the ground at a known position and plays the base station. This technique permits to determine correctly the center of taken images and then directly affect the resolution of reconstructed $3 \mathrm{D}$ images.

\subsection{Camera}

A low cost, commercially available camera, namely called Ricoh GX 200 with built-in SD card is used. One will see later that this camera is adequate and capable of providing high-resolution reconstructed images. Due to the limited efficient load of UAV platform and in order to keep the system to be easy, this camera is used and the installed stabilization plant. This photograph system can provide very high-resolution image for largescale mapping and routine monitoring due to the possibility of very low altitude flying of UAV. 


\subsection{Flight planning and image taking procedure}

The system could be planned to operate in two different modes: (1) autonomously flight and take images at prescribed GPS-defined locations (2) manually flight control (thanks to real-time images observed) and take images at preferred locations. Depending on the targeted applications, resolution requirements, an appropriate flight trajectory will be defined. The distinct and overlapped images will be processed using commercial such as Cartomation (orthogonal image reconstruction) [9], Radmetry (3D image creation) and GIS software [8]. The workflow for UAV mapping is similar to the workflow of man-based aerial mapping system. Flight planning procedure and image processing consists of the determination of the observed area and plan flight trajectory. After the automated data acquisition, out of the acquired raw data products orthoimages, digital surface model (DSM) or 3D models for possible UAV mapping applications.

\section{RESULTS AND DISCUSSIONS}

The UAV-based remote imaging system has been experimented for the Information Technology Park (ITP) of VietNam National University - Ho Chi Minh City (VNU-HCM) area with the cooperation with ISTS company (Information \& Science Techno-System Co. Ltd, Japan) on 29 March, 2010. Figure 4 is the observed area and planned flight trajectory plot on Google Earth framework.

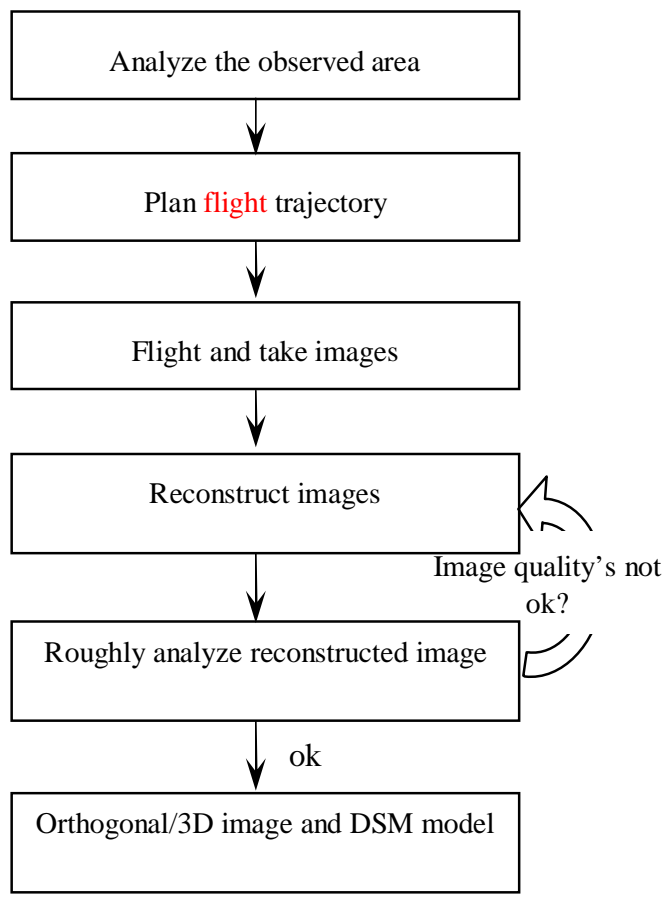

Figure 3. Flight planning procedure and image processing strategy

Table 1 summarizes the dependence of horizontal resolution as function of flight altitudes. One notes that the image resolution decreases as flight altitude increasing.

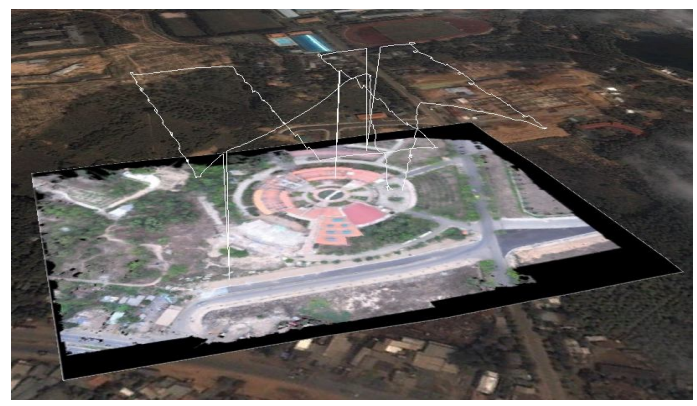

Figure 4. Planned flight trajectory plot on Google Earth 
Table 1. Horizontal resolution evaluation

\begin{tabular}{|c|c|c|c|}
\hline Resolution & $\begin{array}{c}\text { Observed } \\
\text { area }\end{array}$ & $\begin{array}{c}\text { Flight } \\
\text { altitudes }\end{array}$ & $\begin{array}{c}\text { Number } \\
\text { of } \\
\text { images }\end{array}$ \\
\hline $1,1 \mathrm{~cm}$ & $\begin{array}{c}200 \mathrm{~m} x \\
100 \mathrm{~m}\end{array}$ & $30 \mathrm{~m}$ & 99 \\
\hline $3,3 \mathrm{~cm}$ & $\begin{array}{c}240 \mathrm{~m} x \\
240 \mathrm{~m}\end{array}$ & $90 \mathrm{~m}$ & 52 \\
\hline $3,6 \mathrm{~cm}$ & $\begin{array}{c}150 \mathrm{~m} x \\
250 \mathrm{~m}\end{array}$ & $100 \mathrm{~m}$ & 19 \\
\hline $5,5 \mathrm{~cm}$ & $\begin{array}{c}450 \mathrm{~m} x \\
300 \mathrm{~m}\end{array}$ & $150 \mathrm{~m}$ & 36 \\
\hline
\end{tabular}

An image processing software was developed that permits to reconstruct orthogonal image, DSM model and 3D images for large scale area based upon overlapped images (see Figure 5).

\subsection{Horizontal error evaluation}

Table 2 summarize edge dimensions of instances found in observed area and error evaluation results. Here:

+ So: real dimension of instances' edges;

$+\mathrm{S}$ : dimension determined on reconstructed images;

$+n=13$ : number of edges used for error evaluation.

The horizontal dimension error is defined as follows:

$$
\begin{aligned}
m_{m b}= \pm \sqrt{\frac{\left(S-S_{0}\right)^{2}}{n}} & = \pm \sqrt{\frac{94,4}{13}} \\
& = \pm 0,027 \mathrm{~m}= \pm 2,7 \mathrm{~cm}
\end{aligned}
$$

This result helps to confirm the spatial resolution of images reconstructed form UAV- based remote imaging system announced in literatures.

\subsection{Altitude error evaluation}

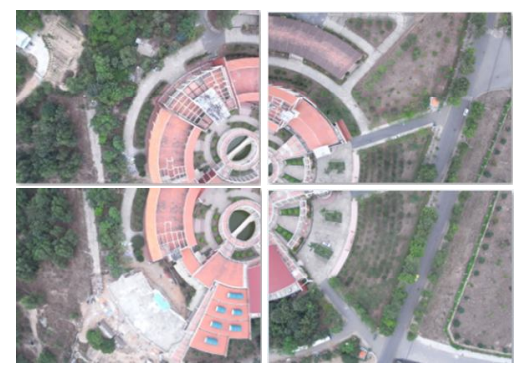

(a) Original taken images

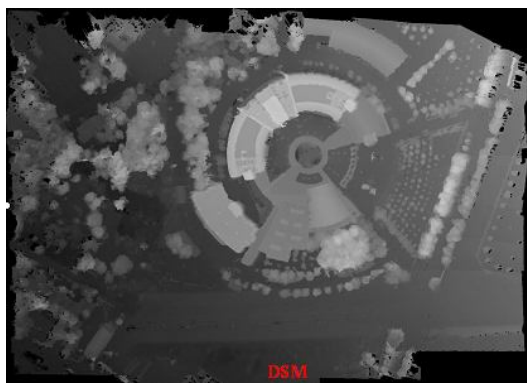

(b) Orthogonal image reconstructed by stitching processing technique

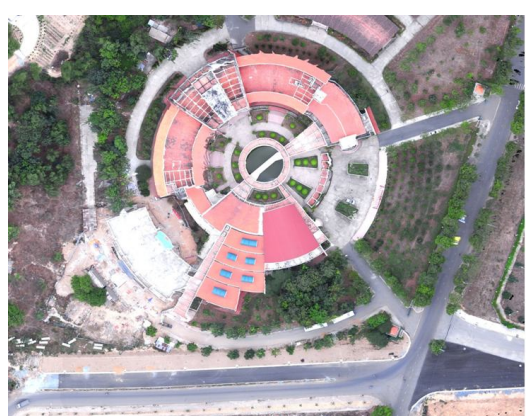

(c) Orthogonal image reconstructed by stitching processing technique

Figure 5. Reconstructed DSM model and orthogonal image of ITP-VNU-HCM Administration Building

Table 3 presents the altitudes of instances in observed area determined by reconstructed 3D image. Here: 
+ ho: real altitudes of controlled points of instances;

$+\mathrm{h}:$ altitudes determined on 3D reconstructed images;

$+n=13:$ number of instance used for error evaluation.

Altitude error is determined as follows:

$$
m_{d c}= \pm \sqrt{\frac{\left[\left(h-h_{0}\right)^{2}\right]}{n}}= \pm \sqrt{\frac{0,493}{13}}=
$$

$\pm 0,195 \mathrm{~m}= \pm 19,5 \mathrm{~cm}$

\section{CONCLUSIONS}

In conclusion, experimental results are very promising and clearly demonstrated the capacity of UAV-based remote imaging system to provide high-resolution image (with resolution lower than $3 \mathrm{~cm}$ in horizontal plane and lower than $20 \mathrm{~cm}$ in altitude) for small areas with quite low cost. This opens a new way to build up high resolution $3 \mathrm{D}$ images for small and constrained areas in real time with quite low costs.

Table 2. Edge dimension and error evaluation

\begin{tabular}{|c|c|c|c|c|c|}
\hline № & Edges & $\begin{array}{l}\mathbf{S}_{0} \\
(\mathrm{~m})\end{array}$ & $\begin{array}{c}\mathrm{S} \\
(\mathrm{m})\end{array}$ & $\begin{array}{l}S-S_{0} \\
(\mathrm{~cm})\end{array}$ & $\begin{array}{c}\left(S-S_{0}\right)^{2} \\
\left(\mathrm{~cm}^{2}\right)\end{array}$ \\
\hline 1 & A & 4,40 & 4,427 & 2,7 & 7,29 \\
\hline 2 & B & 2,00 & 1,988 & $-1,2$ & 1,44 \\
\hline 3 & $\mathrm{c}$ & 6,75 & 6,749 & $-0,1$ & 0,01 \\
\hline 4 & $d$ & 12,48 & 12,494 & 1,4 & 1,96 \\
\hline 5 & $\mathrm{e}$ & 12,26 & 12,281 & 2,1 & 4,41 \\
\hline 6 & f & 12,40 & 12,391 & $-0,9$ & 0,81 \\
\hline 7 & g & 6,60 & 6,586 & $-1,4$ & 1,96 \\
\hline 8 & $\mathrm{~h}$ & 6,77 & 6,708 & $-6,2$ & 38,44 \\
\hline 9 & i & 6,00 & 5,981 & $-1,9$ & 3,61 \\
\hline 10 & $\mathrm{k}$ & 6,00 & 6,019 & 1,9 & 3,61 \\
\hline 11 & 1 & 6,04 & 6,046 & 0,6 & 0,36 \\
\hline 12 & $\mathrm{~m}$ & 1,035 & 1,040 & 0,5 & 0,25 \\
\hline 13 & $\mathrm{n}$ & 0,935 & 0,990 & 5,5 & 30,25 \\
\hline \multicolumn{5}{|c|}{ Sum } & 94,4 \\
\hline
\end{tabular}


Table 3. Determined altitudes of objects and error evaluation

\begin{tabular}{|c|c|c|c|c|c|}
\hline $\mathbf{N} \mathbf{0}$ & Objects & $\mathbf{h}_{\mathbf{0}}(\mathbf{m})$ & $\mathbf{h}(\mathbf{m})$ & $\mathbf{h}-\mathbf{h}_{\mathbf{0}}(\mathbf{m})$ & $\left(\mathbf{h}-\mathbf{h}_{\mathbf{0}}\right)^{\mathbf{2}}\left(\mathbf{m}^{\mathbf{2}}\right)$ \\
\hline 1 & P1 & 5,25 & 5,2 & $-0,05$ & 0,002 \\
\hline 2 & P2 & 5,25 & 4,9 & $-0,35$ & 0,123 \\
\hline 3 & P3 & 5,25 & 4,9 & $-0,35$ & 0,123 \\
\hline 4 & P4 & 5,3 & 5,5 & 0,2 & 0,040 \\
\hline 5 & P5 & 6,18 & 6,1 & $-0,08$ & 0,006 \\
\hline 6 & P6 & 19,745 & 19,7 & $-0,045$ & 0,002 \\
\hline 7 & P7 & 18,9 & 19,2 & 0,3 & 0,090 \\
\hline 8 & P8 & 5,3 & 5,4 & 0,1 & 0,010 \\
\hline 9 & P9 & 5,25 & 5 & $-0,25$ & 0,063 \\
\hline 10 & P10 & 6,18 & 6,2 & 0,02 & 0,000 \\
\hline 11 & P11 & 5,56 & 5,4 & $-0,16$ & 0,026 \\
\hline 12 & P12 & 5,18 & 5,1 & $-0,08$ & 0,006 \\
\hline 13 & P13 & 3,25 & 3,3 & 0,05 & 0,002 \\
\hline & & & & & $\mathbf{0}, 493$ \\
\hline
\end{tabular}

\section{XÂY DỰNG Hệ THỐNG THU NHậN ẢNH ĐỘ PHÂN GIẢI CAO SỬ DỤNG MÁY BAY KHÔNG NGƯÒ̀I LÁI}

\section{Lê Văn Trung ${ }^{(1)}$, Nguyễn Anh Thi ${ }^{(2)}$}

(1) Khu Công Nghệ Phần Mềm, ĐHQG-HCM

(2) ĐHQG-HCM

TÓM TẮT: Hệ thống thu nhận ảnh viến thám độ phân giải cao, giá thành thấp sủ dụng máy bay không người lái kiểu cất hạ cánh thẳng đưng, hoạt động linh hoạt trong điều kiện địa hình phức tạp, có khả năng bay và chụp ảnh ở cao độ thấp tì $10 \mathrm{~m}$ đến $300 \mathrm{~m}$ đã được xây dụng, bay thử nghiệm và đánh giá trong diều kiện Việt Nam. Kết quả thu nhận ảnh thử nghiệm cho thấy hệ thống có khả năng thu nhận ảnh với độ chính xác theo phuơng ngang nhỏ hơn $3 \mathrm{~cm}$ và độ chính xác cao độ nhỏ hơn $20 \mathrm{~cm}$. Nghiên cứu mở ra một giải pháp mới, hiệu quả để xây dụng ảnh viễn thám độ chính xác cao, thời gian thực phục vu các ứng dụng dân sinh - quốc phòng quan trọng.

Tù khóa: Máy bay không người lái, kiểu cất hạ cánh thẳng đứng, tạo ảnh viễn thám 


\section{REFERENCES}

[1]. Harintaka, Subaryono, A. Susanto, Hartono, Assessment of Low Cost Small Format Aerial Photogrammetry for Cadastral Mapping, 7th FIG Regional Conference on Spatial Data Serving People: Land Governance and the Environment - Building the Capacity, 1922, Hanoi, Vietnam (2009).

[2]. H. Eisenbeiss, K. Lambers, M. Sauerbier, Z. Li, Photogrammetric documentation of an archaeological site (Palpa, Peru) using an autonomous model helicopter, CIPA XX International Symposium, Torino, Italy (2005)

[3]. P. Patias, C. Saatsoglou-Paliadeli, O. Georgoula, M. Pateraki, A. Stamnas, N. Kyriakou, Photogrammetric documentation and digital representation of the macedonian palace in verginaaegeae, XXI International CIPA Symposium, 01-06, Athens, Greece (2007).

[4]. H. Eisenbeiss, Processing and Visualization Using High-Resolution Imagery, International Workshop on Processing and Visualization using HighResolution Imagery, 18-20, Topland Hotel - Pitsanulok, Thailand (2004).

[5]. J. Everaerts, N. Lewyckyj, D. Fransaer, Design of a Stratospheric Long Endurance
UAV System for Remote Sensing, The International Archives of the Photogrammetry, Remote Sensing and Spatial Information Sciences, Istanbul, Turkey, GITC, Lemmer, The Netherlands

[6]. J. Everaerts, The Use of Unmanned Aerial Vehicles (UAVs) for Remote Sensing and Mapping, The International Archives of the Photogrammetry, Remote Sensing and Spatial Information Sciences, XXXVII. Part B1. Beijing (2008).

[7]. A. Lucieer, S. Robinson, D.J. Turner, Using an Unmanned Aerial Vehicle (UAV) for Ultra-High Resolution Mapping of Antarctic Moss Beds, Proceedings of the Australasian Remote Sensing and Photogrammetry Conference, Alice Springs (2010).

[8]. J. G. Liu, P. J. Mason, Essential Image Processing and GIS for Remote Sensing, Wiley-Blackwell (2009).

[9]. http://www.cartomation.com

[10]. http://www.ists.co.jp 